Int. J. Environ. Res. Public Health 2004, 1(2), 132-137

International Journal of

\title{
Metal Ion Effect on BOD Exertion at Different Temperatures
}

\author{
Susheel K Mittal*, Siloni Goel and Ajay Sharma \\ School of Chemistry and Biochemistry, Thapar Institute of Engineering \& Technology (Deemed University) Patiala, \\ 147004, India \\ *Correspondence to Dr. Susheel K. Mittal. Email: smittal@tiet.ac.in
}

Received: 25 July 2004 / Accepted: 26 August 2004 / Published: 30 September 2004

\begin{abstract}
The toxic effect of metal ions like chromium $\left(\mathrm{Cr}^{3+}\right)$, cobalt $\left(\mathrm{Co}^{2+}\right)$, nickel $\left(\mathrm{Ni}^{2+}\right)$, copper $\left(\mathrm{Cu}^{2+}\right)$, cadmium $\left(\mathrm{Cd}^{2+}\right)$ and lead $\left(\mathrm{Pb}^{2+}\right)$ on biochemical oxygen demand (BOD) of synthetic wastewater samples has been studied at different temperatures i.e., $15^{\circ} \mathrm{C}, 20^{\circ} \mathrm{C}, 25^{\circ} \mathrm{C}$ and $30^{\circ} \mathrm{C}$. Experiments were conducted for BOD exertion in presence (10 ppm of each metal ion) and in the absence of metal ions at different temperatures. Transition metal ions like $\mathrm{Cr}^{3+}, \mathrm{Co}^{2+}, \mathrm{Ni}^{2+}$ and $\mathrm{Cu}^{2+}$ show an increase in relative percentage inhibition with increasing atomic number. BOD inhibition in presence of $\mathrm{Cd}^{2+}$ and $\mathrm{Pb}^{2+}$ is relatively large. The metal ions under study are found to be highly toxic to microbes.
\end{abstract}

Keywords: BOD, metal ion effect, temperature

\section{Introduction}

Since both the aerobic biological treatment process and BOD measuring technique (using dilution method) are based on the same principle, the presence of metals like copper, zinc, lead and other heavy metals will have an influence on both processes. Because of the limited solubility of oxygen in the aqueous medium in BOD bottle, the effect of heavy metals will be sufficiently large as compared to that in the treatment plant because the effluent in the treatment plant gets a regular supply of oxygen from continuous aeration.

Trace quantities of heavy metals such as nickel, manganese, lead, chromium, cadmium, zinc, copper, ferrous and mercury are common constituents of most wastewaters. Some of these metals are necessary for growth of biological life and the absence of sufficient quantities of them could limit growth of algae. However, the presence of any of these metals in excessive quantities will interfere with many beneficial uses of water because of their toxicity. Nriagu [1] reported the effects of $\mathrm{Hg}, \mathrm{Cu}, \mathrm{Zn}, \mathrm{Cd}$ and $\mathrm{Pb}$ on algae photosynthesis in the lakes. $\mathrm{Zn}$ and $\mathrm{Cd}$ inhibited the photosynthetic activity strongly in summer.

Very little work is available in literature on the effect of temperature on heavy metal toxicity to BOD. Apparently, BOD is expected to increase with the increase in temperature of incubation because of the loss of dissolved oxygen from the medium of heavy metal ions. It will be quite interesting to see the effect on BOD particularly with an increase in temperature

It has been reported that $\mathrm{BOD}_{5}$ is suppressed significantly by even small concentrations (1-2 mg/L) of copper or chromium. Stone [2] measured the percentage of suppression caused by $1 \mathrm{mg} / \mathrm{L}$ of selected heavy metals on the BOD of domestic sewage. Gray [3] found that $6 \mathrm{mg} / \mathrm{L}$ mercury chloride, $40 \mathrm{mg} / \mathrm{L}$ of copper sulphate or $30 \mathrm{mg} / \mathrm{L}$ of potassium dichromate were required to completely inhibit bacterial activity on a sample of glucose. Mayo [4] studied the effect of temperature and $\mathrm{pH}$ on the growth of micro organisms and has defined the optimum temperature and $\mathrm{pH}$ as those at which the growth rate of micro organisms is the highest. 
According to another study by Mittal and Ratra [5], the presence of metal ions like $\mathrm{Al}, \mathrm{Co}, \mathrm{Ni}, \mathrm{Cu}, \mathrm{Zn}, \mathrm{Pb}$ and $\mathrm{Hg}$ in the effluent samples significantly affects BOD values. Metal ion addition results in the inhibition as well as increase in BOD, depending on its concentration.

The present study was undertaken to determine the effect of heavy metal ions on BOD when the temperature of the medium is varied in the ambient temperature range. The reported work may have more relevance for common effluent treatment plants, and municipal wastes that contain both inorganic and organic effluents.

\section{Materials and Methods}

The ambient temperature range $\left(15^{\circ} \mathrm{C}-30^{\circ} \mathrm{C}\right.$ with an incremental change of $5^{\circ} \mathrm{C}$ ) was selected for the study, as a variety of microbes responsible for BOD exertion are optimally active in this temperature range. Experiments were conducted at selected temperatures of incubation to measure $\mathrm{BOD}$ in the absence and in the presence of some heavy metal ions. Five-day BOD $\left(\mathrm{BOD}_{5}\right)$ measurements were used as assessment end points.

\section{Sampling and Storage}

Samples were prepared synthetically in the laboratory and stored in the refrigerator at $4^{\circ} \mathrm{C}$. At the time of conducting the experiment, samples were first brought at the room temperature.

\section{Apparatus}

Incubation bottles (300 mL capacity) were washed, rinsed thoroughly with distilled water and drained before use. As a precaution against drawing air in the dilution bottle during incubation, a water seal was used. To reduce evaporation of water from the seal, during incubation placed an aluminium foil cap over flared mouth of the bottle. Four BOD incubators thermostatically controlled at $15^{\circ} \mathrm{C}, 20^{\circ} \mathrm{C}, 25^{\circ} \mathrm{C}$ and $30^{\circ} \mathrm{C}$ $\left( \pm 0.1^{\circ} \mathrm{C}\right)$ were used for the tests.

\section{Reagents}

All reagents were prepared as per procedures given in Standard Methods for the Examination of Water and Waste [6].

\section{Procedure}

\section{Preparation of Dilution Water}

A desired volume of distilled/deionised water was put in a suitable container, and $1 \mathrm{~mL} /$ litre of each of the phosphate buffer, $\mathrm{MgSO}_{4}, \mathrm{CaCl}_{2}$ and $\mathrm{FeCl}_{3}$ solutions were added to the seeded dilution water, as described in following paragraph. Dilution water was brought to room temperature before use, and saturated with dissolved oxygen by shaking for 15 minutes.

\section{Seeding}

A compatible seed from treatment plant of a local milk plant, Sirhind Road, Patiala was collected. The seed was taken from a corner of aeration tank and immediate before the settling tank. The effluent water (seed) was aerated and then allowed to settle. The supernatant liquid was then used as a "seed" for the BOD test. $1 \mathrm{~mL}$ of seed per litre of dilution water was added in nutritioned dilution water.

\section{Seed Control}

BOD of seeding material was measured and dilutions were made so that its DO uptake comes between 0.6 to $1.25 \mathrm{mg} / \mathrm{L}$.

\section{Preparation of Synthetic Waste Sample}

Synthetic waste sample was prepared from raw milk (Verka, Standard Shakti) in the laboratory. Synthetic sample was preferred to the actual waste samples from industrial effluents because the work is of relative nature and effect of toxicity was to be observed. Because industrial sample may contain matter other than organic material such as detergents, heavy metals, chemicals and other foreign materials, which may interfere along with the toxic metals under test. Raw milk has BOD about 70,000 to $100,000 \mathrm{mg} / \mathrm{L}$ and was diluted so that its BOD comes in the range of $700-1000 \mathrm{mg} / \mathrm{L}$. For that $5 \mathrm{~mL}$ of raw milk was added in about $500 \mathrm{~mL}$ distilled water and diluted further to make it one litre.

\section{Preparation of Metal Ion Solutions}

Metal ions selected for study were chromium, cobalt, nickel, copper, cadmium and lead. Appropriate amounts of their salts were dissolved in distilled water and dilutions were done to prepare a 1000-ppm stock solution of each metal ion.

\section{Estimation of BOD}

$\mathrm{BOD}_{5}$ measurement was done in presence of each one of all the six metal ions taken for the present study. Based on our previous study (Mittal and Ratra, 2000) a concentration of $10 \mathrm{mg} / \mathrm{L}$ was selected. For each metal concentration, three replicas were taken and the mean was used for subsequent calculations.

1.5mL (1: 200) sample was taken in each bottle (300 $\mathrm{mL}$ capacity) so that the BOD lies between 700-1000 $\mathrm{mg} / \mathrm{L}$. Therefore, maximum expected DO depletion would have been between 3.5 to $5.0 \mathrm{mg} / \mathrm{L}$. As the saturated DO in summer days is usually around 7.0 $\mathrm{mg} / \mathrm{L}$, a minimum of $1-2 \mathrm{mg} / \mathrm{L}$ of DO would have remained in the test solution even in case of maximum depletion, which is an essential norm for the BOD test.

All the bottles were filled carefully with seeded dilution water to the top of the brim. Water was not 
allowed to overflow as it would disturb the concentration of metal ions in bottle. Initial DO of first bottle of each set was taken and remaining three were capped, water sealed and incubated for five days at $15^{\circ} \mathrm{C}, 20^{\circ} \mathrm{C}, 25^{\circ} \mathrm{C}$ and $30^{\circ} \mathrm{C}$ in BOD incubators. After five days incubation, final DO of samples was determined.

\section{Estimation of Dissolved Oxygen}

Initial and final DO values were determined by titration method. Alsterberg modification of Wrinkler's method was adopted. Percentage of inhibition in BOD values (due to toxicity of metal ions) were calculated for each metal ion at different temperatures, and are shown in Table 1.

Table 1: BOD Inhibition as a function of temperature in presence of different metal ions

\begin{tabular}{|c|c|c|c|c|c|c|}
\hline \multirow{2}{*}{$\begin{array}{l}\text { Temperature } \\
\left({ }^{\circ} \mathrm{C}\right)\end{array}$} & \multicolumn{6}{|c|}{$\begin{array}{c}\text { Percentage inhibition in BOD exertion } \\
\text { by metal ions }\end{array}$} \\
\hline & $\mathrm{Cr}^{3+}$ & $\mathrm{Co}^{2+}$ & $\mathrm{Ni}^{2+}$ & $\mathrm{Cu}^{2+}$ & $\mathrm{Cd}^{2+}$ & $\mathrm{Pb}^{2+}$ \\
\hline 15 & 22.0 & 37.9 & 38.5 & 20.4 & 40.1 & 48.1 \\
\hline 20 & 51.6 & 41.9 & 40.9 & 43.6 & 46.1 & 54.6 \\
\hline 25 & 64.1 & 56.4 & 50.2 & 59.1 & 65.7 & 74.9 \\
\hline 30 & 59.5 & 53.9 & 45.8 & 50.1 & 60.9 & 56.6 \\
\hline
\end{tabular}

\section{Statistical Analysis of the Data}

A number of measurements were carried out for each experiment of BOD. The results are reported in Table 2 and the standard deviations for each measurement are given. Mean BOD value in presence of a given metal ion is subtracted from the mean BOD without the metal ion to calculate the inhibition. Histograms of the BOD without metal ion as well as those in presence of metal ion are plotted. Error bars for each histogram represent the standard deviation in the BOD values. Inhibitions in BOD due to the presence of metal ion are shown in the figure as separate columns. No error bars can be given for BOD inhibition as the results are the differences in mean BOD values.

\section{Results and Discussion}

BOD exertion is affected by factors like temperature, availability of organic matter as food [7], seed [8-9], and $\mathrm{pH}$ of the medium [10]. Present study is undertaken to study the effect of some heavy metal ions like $\mathrm{Cr}^{3+}, \mathrm{Co}^{2+}$, $\mathrm{Ni}^{2+}, \mathrm{Cu}^{2+}, \mathrm{Cd}^{2+}$ and $\mathrm{Pb}^{2+}$ on $\mathrm{BOD}$ at different temperatures, i.e., $15^{\circ} \mathrm{C}, 20^{\circ} \mathrm{C}, 25^{\circ} \mathrm{C}$ and $30^{\circ} \mathrm{C}$. Experiments were conducted for BOD exertion in presence of $10 \mathrm{ppm}$ of each metal ion. This concentration was selected on the basis of our previous study [5] where an appreciable change in BOD was recorded due to the presence of 10ppm of the metal ion concentration. $\mathrm{BOD}_{5}$ was determined in the absence as well as in the presence of the metal ions.

All metal ions are found to inhibit the BOD (Table 1). Absolute values of BOD in presence of metal ions are compared with those in the absence of metal ions at different temperatures and are shown in Figures 1- 4. These Figures also show inhibition in BOD in the presence of metal ions at a given temperature. Relative percentage inhibition increases with increase in temperature (Table 1 ) up to $25^{\circ} \mathrm{C}$ and further up to $30^{\circ} \mathrm{C}$ it tends to decrease, probably because of the relatively large increase in BOD exertion for the blank system from $25^{\circ} \mathrm{C}$ to $30^{\circ} \mathrm{C}$ (an increase of $\sim 400 \mathrm{mg} / \mathrm{L}$ as compared to $\sim 100 \mathrm{mg} / \mathrm{L}$ and $\sim 140 \mathrm{mg} / \mathrm{L}$ for temperatures $15^{\circ} \mathrm{C}$ to $20^{\circ} \mathrm{C}$ and $20^{\circ} \mathrm{C}$ to $25^{\circ} \mathrm{C}$, respectively).

In all the metal ions, relative percentage inhibition is more at $25^{\circ} \mathrm{C}$ than at all other temperatures. Lead is found to be the most toxic element at all temperatures. $\mathrm{Cd}^{2+}$ and $\mathrm{Pb}^{2+}$ show relatively larger inhibition than that of transition elements. It shows that transition metals as well as $\mathrm{Cd}^{2+}$ and $\mathrm{Pb}^{2+}$ are highly toxic to microbes.

Table 2 shows that BOD in the absence of any metal ion increases from $857 \pm 15 \mathrm{mg} / \mathrm{L}$ at $15^{\circ} \mathrm{C}$ to $970 \pm 26$ $\mathrm{mg} / \mathrm{L}$ at $20^{\circ} \mathrm{C}$. This increase of $100 \mathrm{mg} / \mathrm{L}$ is relatively less as compared to the increases of $\sim 150$ and $\sim 400 \mathrm{mg} / \mathrm{L}$ for the increase in temperatures from $20^{\circ} \mathrm{C}$ to $25^{\circ} \mathrm{C}$ and $25^{\circ} \mathrm{C}$ to $30^{\circ} \mathrm{C}$, respectively. This is due to the reason that upto $20^{\circ} \mathrm{C}$, population of the nitrifying bacteria is not enough to contribute appreciably to the normal $\mathrm{BOD}_{5}$ exertion, but at $25^{\circ} \mathrm{C}$ and $30^{\circ} \mathrm{C}$ nitrogenous BOD adds up to the normal BOD. There are primarily two reasons for the increase in BOD from $15^{\circ} \mathrm{C}$ to $30^{\circ} \mathrm{C}$;

I. Depletion of dissolved oxygen $(\mathrm{mg} / \mathrm{L})$ with increase in temperature. Solubility of oxygen in water at 760 $\mathrm{mm}$ of mercury pressure and $100 \%$ relative humidity are: $10.07\left(15^{\circ} \mathrm{C}\right), 9.08\left(20^{\circ} \mathrm{C}\right), 8.27$ $\left(25^{\circ} \mathrm{C}\right)$ and $7.59\left(30^{\circ} \mathrm{C}\right)$.

II. Due to the toxic behaviour of metal ions towards microbes (metal ions complexing with microbial cells) resulting in a lower demand of dissolved oxygen.

A peer look into Table 1 shows that the relative percentage inhibition increases almost linearly with increase in temperature up to $25^{\circ} \mathrm{C}$ in the presence of each metal ion. It indicates that the metal microbe complex is stabilized with increase in temperature up to $25^{\circ} \mathrm{C}$. For most of the metals, except copper, the relative percentage inhibition lies between $40 \%$ and $60 \%$. Presence of lead in the BOD bottle leads to an exceptionally large inhibition with very little dependence on temperature.

The recorded inhibition at $30^{\circ} \mathrm{C}$ is besides the effect of nitrifying bacteria. In their absence the inhibition would have been still larger. These bacteria are known to be most active in a temperature range $30^{\circ} \mathrm{C}-40^{\circ} \mathrm{C}$. 
Table 1: BOD exertion as a function of temperature in presence of different metal ions

\begin{tabular}{|c|c|c|c|c|c|c|c|c|c|c|c|c|c|}
\hline \multirow{3}{*}{$\begin{array}{c}\text { Temperature } \\
\left({ }^{\circ} \mathrm{C}\right)\end{array}$} & \multirow{3}{*}{$\begin{array}{c}\text { BOD without } \\
\text { metal ion } \\
(\mathrm{mg} / \mathrm{L})\end{array}$} & \multicolumn{12}{|c|}{ BOD exertion in presence of metal ions, $\mathrm{mg} / \mathrm{L}$} \\
\hline & & \multicolumn{2}{|c|}{ Chromium } & \multicolumn{2}{|c|}{ Cobalt } & \multicolumn{2}{|c|}{ Nickel } & \multicolumn{2}{|c|}{ Copper } & \multicolumn{2}{|c|}{ Cadmium } & \multicolumn{2}{|c|}{ Lead } \\
\hline & & (b) & $(a-b)$ & (c) & $(a-c)$ & (d) & $(a-d)$ & (e) & $(a-e)$ & $(f)$ & $(a-f)$ & (g) & $(a-g)$ \\
\hline 15 & $857 \pm 15$ & $677 \pm 25$ & 180 & $532 \pm 13$ & 325 & $527 \pm 15$ & 330 & $682 \pm 13$ & 175 & $513 \pm 15$ & 343 & $445 \pm 5$ & 412 \\
\hline 20 & $970 \pm 26$ & $470 \pm 26$ & 500 & $563 \pm 15$ & 407 & $573 \pm 15$ & 397 & $547 \pm 8$ & 423 & $523 \pm 10$ & 447 & $440 \pm 5$ & 530 \\
\hline 25 & $1123 \pm 25$ & $403 \pm 15$ & 720 & $490 \pm 10$ & 633 & $560 \pm 10$ & 563 & $460 \pm 10$ & 663 & $385 \pm 5$ & 738 & $282 \pm 8$ & 842 \\
\hline 30 & $1480 \pm 20$ & $600 \pm 15$ & 880 & $682 \pm 20$ & 798 & $802 \pm 18$ & 698 & $738 \pm 8$ & 742 & $578 \pm 8$ & 902 & $642 \pm 37$ & 838 \\
\hline
\end{tabular}

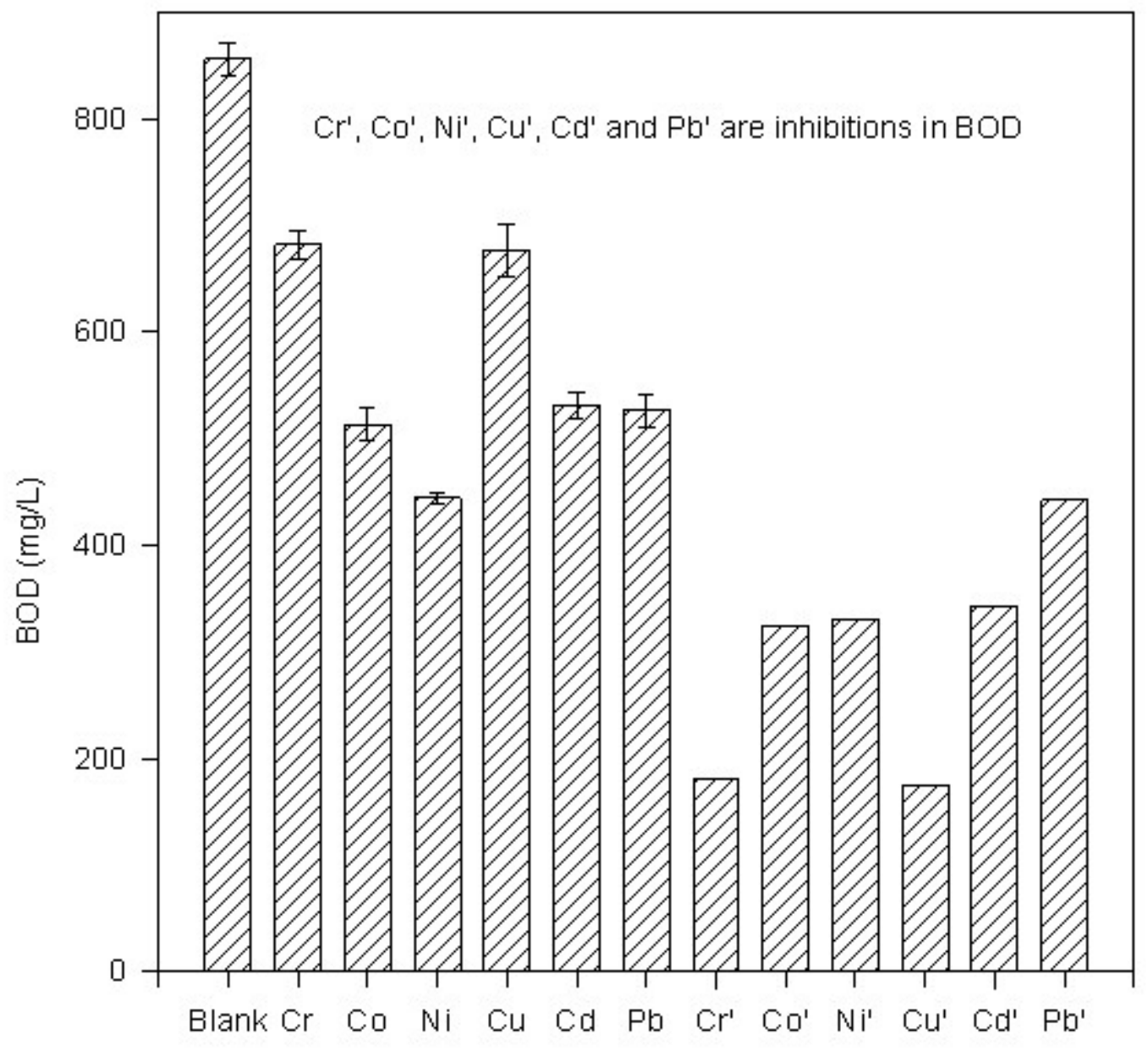

Figure 1: Histogram of BOD in presence of metal ions at $15^{\circ} \mathrm{C}$ 


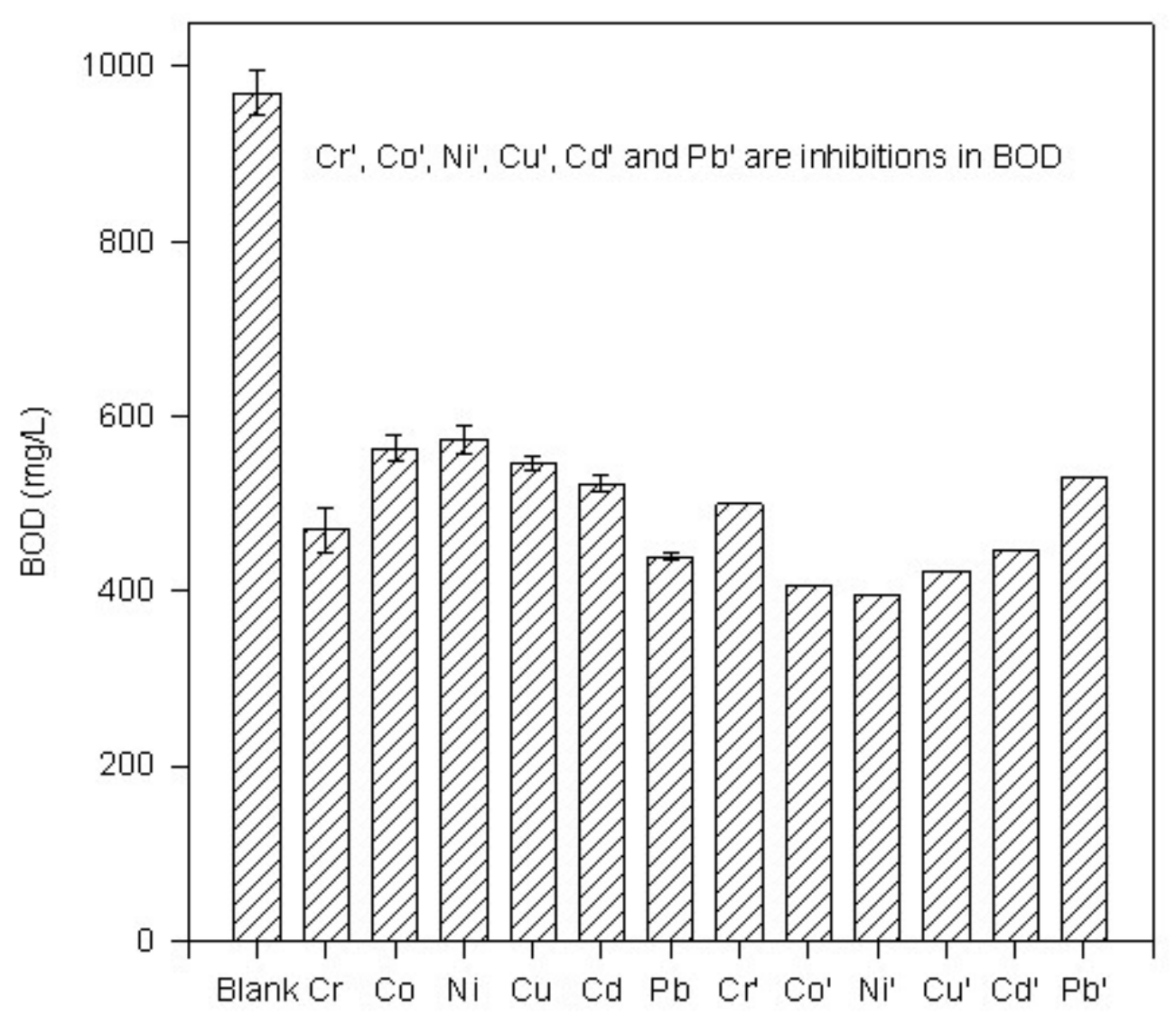

Figure 2: Histogram of BOD in presence of metal ions at $20^{\circ} \mathrm{C}$

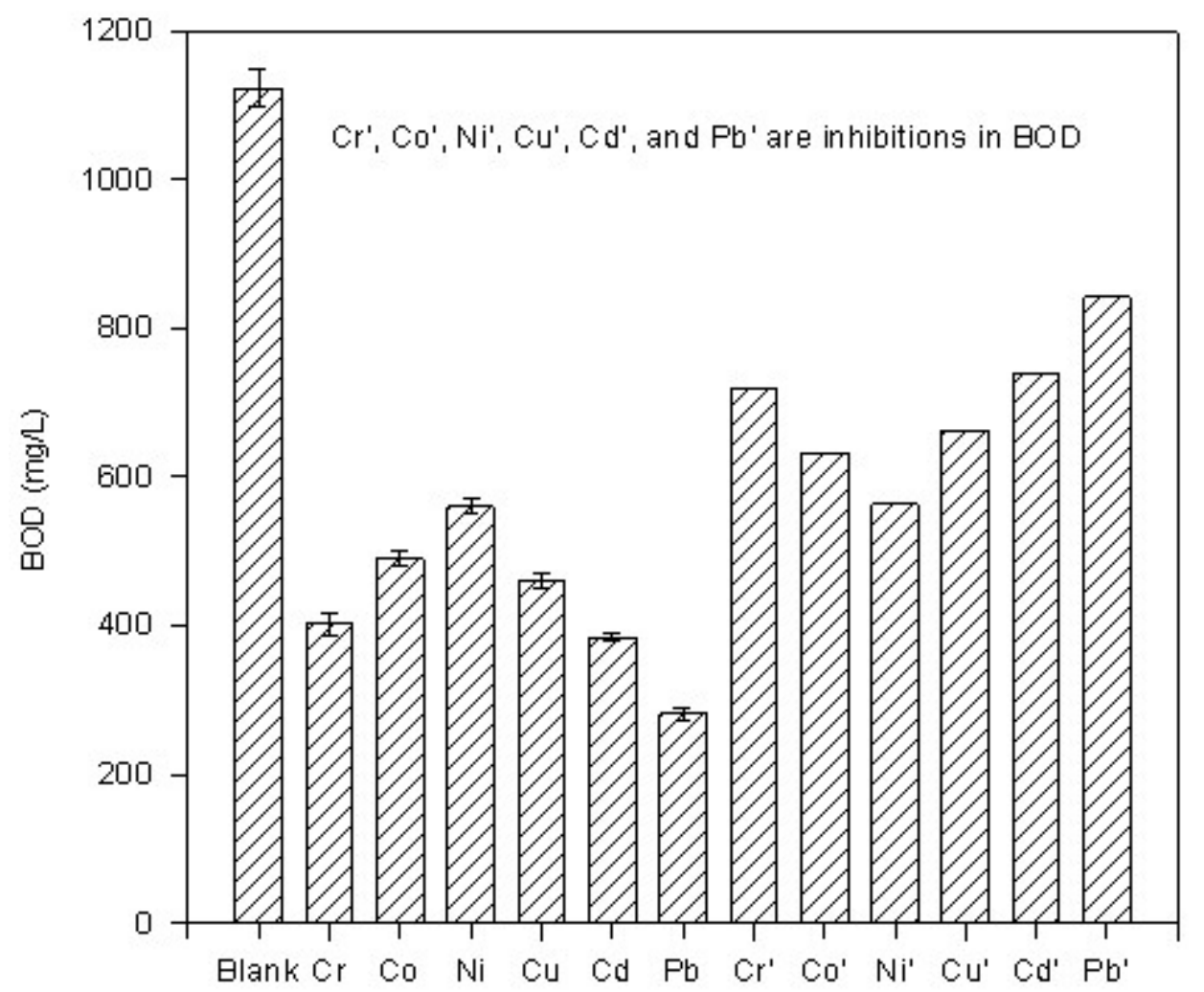

Figure 3: Histogram of BOD in presence of metal ions at $25^{\circ} \mathrm{C}$ 


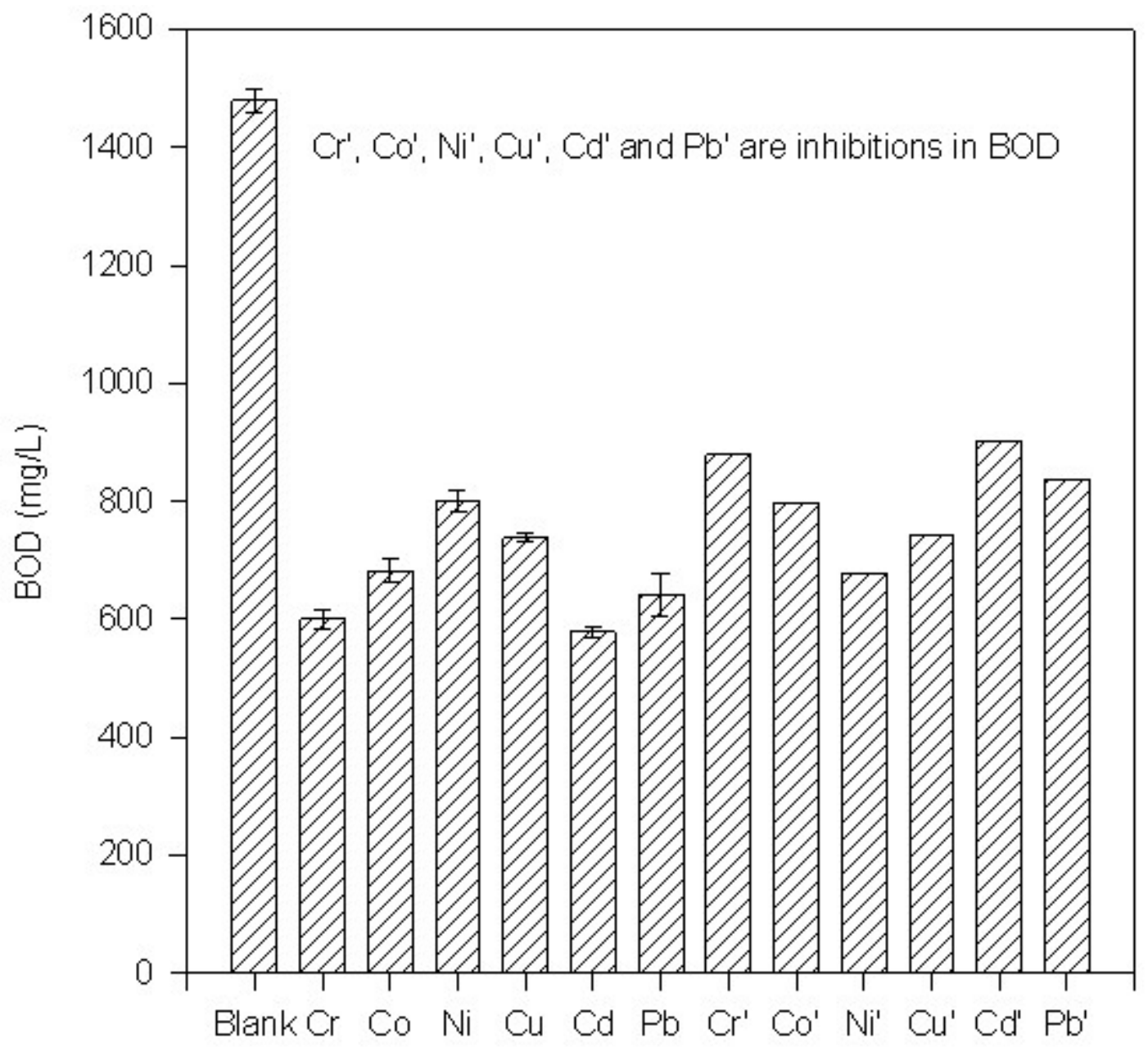

Figure 4: Histogram of BOD in presence of metal ions at $30^{\circ} \mathrm{C}$

\section{Conclusions}

Measurements of BOD can be influenced by the temperature of the solution by acting on properties of substances present like microbes, metal ions in the sample. Complexation phenomenons are strongly dependent on temperature. It is therefore recommended that BOD be measured for different temperature values.

Acknowledgement: The authors are thankful to the Director, Thapar Institute of Engineering and Technology, Patiala for providing research facilities.

\section{References}

1. Nriagu, J. O.: Cadmium in Environment Part-I Ecological Cycling. A Wiley Interscience Publication, 1980, 572-84.

2. Stone, T.: A resume of the Kinetics of BOD Test. Water Pollution Control, Midstone; Engl. 1981, 80(4), 513-20.

3. Gray, N. F.: Biology of Wastewaters Treatment. Oxford Science Publication, 1989.
4. Mayo, Alice W.: Effect of Temperature and $\mathrm{pH}$ on the Kinetic Growth of Unialga Chlorella Vulgaris Cultures Containing Bacteria, Water Environment Research, 1997, 69(1), 64-71.

5. Mittal, S. K.; Ratra, R. K.: Toxic Effect of Metal Ions Biochemical Oxygen Demand. Water Research, 2000, 34(1), 147-152.

6. APHA, AWWA and WPCF, Standard Methods for the Examination of Water and Wastewater, $20^{\text {th }}$ Edition 2000, Jointly edited by Eaton, Andrew D.; Clesceri, Lenore S.; Greenberg, Arnold E.

7. Harward, S. P.: Environmental Engineering. McGraw Hill International Edition, 1998.

8. Mittal S. K.; Siloni Goel.: Role of Living Organisms in BOD exertion in presence of heavy metal ions. Indian Journal of Environment Protection, 2004, 23(7).

9. Shrivastava A. K.; Jyoti Swaroop; Neeraj Jain.: Effect of seed on BOD exertion. Indian J. of Environ. Health 2000, 42(2), 75-78.

10. Mittal S. K.; Siloni Goel.: BOD exertion in presence of some heavy metal ions: The $\mathrm{pH}$ effect. Pollution Research (In press). 